\title{
SEPT4 wt Allele
}

National Cancer Institute

\section{Source}

National Cancer Institute. SEPT4 wt Allele. NCI Thesaurus. Code C104503.

Human SEPT 4 wild-type allele is located in the vicinity of $17 q 22$ and is approximately 20

$\mathrm{kb}$ in length. This allele, which encodes septin- 4 protein, plays a role in both GT P

hydrolysis and the structure of the cytoskeleton. 